\title{
The use of cashew apple residue as source of fiber in low fat hamburgers
}

\author{
Uso do resíduo do pedúnculo de caju como fonte de fibras em hambúrguer com baixo teor de gordura
}

\author{
Lívia Xerez $\mathrm{PINHO}^{1}$, Marcos Rodrigues Amorim $\mathrm{AFONSO}^{1 *}$, José Osvaldo Beserra CARIOCA ${ }^{1}$, \\ José Maria Correia da COSTA ${ }^{1}$, Afonso Mota RAMOS ${ }^{2}$
}

\begin{abstract}
The main purpose of this study was to produce hamburgers with partial substitution of the meat with cashew apple residue powder. The powder residue was obtained after the extraction of the pulp and dehydration in stove with air circulation. Three formulations of hamburgers with increasing concentration of the residue as well as a control sample were prepared. The formulated products with cashew apple residue powder presented lower humidity and proteins and 35\% lipid reduction. However, there was an increase in carbohydrates and $\mathrm{pH}$ with the addition of the powder from the cashew apple residue. Some formulations showed an improvement of the final product yield. The total dietary fiber value was between 0 and $7.66 \%$, with higher content of insoluble dietary fiber. The addition of up to $10.70 \%$ of the residue did not cause significant sensory changes in the flavor of the samples. The production of hamburgers with a partial substitution of cow meat with the cashew apple residue could be a feasible option since it resulted in product with high nutritional quality that is rich or have high dietary fiber content and is low in fat.
\end{abstract}

Keywords: new products; meat; acceptance.

\section{Resumo}

O objetivo deste trabalho foi elaborar hambúrgueres com substituição parcial de carne bovina por resíduo de pedúnculo de caju em pó. O resíduo em pó foi obtido após extração da polpa e desidratação em estufa com circulação de ar. Foram elaboradas três formulações de hambúrgueres com quantidades crescentes do resíduo e uma amostra controle. Os produtos formulados com resíduo em pó do pedúnculo de caju apresentaram valores menores para a umidade, as proteínas e até 35\% de redução para os lipídios, porém, houve aumento dos carboidratos bem como do $\mathrm{pH}$ com o acréscimo desse resíduo. Algumas formulações apresentaram aumento no rendimento do produto final.Os teores de fibra alimentar total obtidos foram entre 0 e 7,66\%, com maior conteúdo em fibra alimentar insolúvel. A adição de até 10,70\% do resíduo não causou mudanças sensoriais significativas no sabor das amostras. A produção de hambúrgueres com substituição parcial de carne bovina por resíduo de pedúnculo de caju pode ser uma opção viável, gerou um produto com boa qualidade nutricional, rico ou com elevado teor de fibra alimentar e light em lipídios.

Palavras-chave: produtos novos; carne; aceitação.

\section{Introduction}

New food products are prepared to satisfy costumer's demands concerning taste, appearance, value, and comfort. Hamburgers are reasonably priced, highly consumed food products, which have great acceptability in many regions around the world. Despite being considered as a high caloric value food, hamburgers can be produced with good quality raw materials and can be enriched with some ingredients that could offer some functional properties.

The fat present in foods can be reduced by simple techniques such as water dilution or the substitution of fat with ingredients like fruit pulp or other specific compounds for this purpose. These ingredients can be employed to supply part or all functions of the fat, but with less fat and calories (JONNALAGADDA; JONES, 2005).

Cashews have a great amount of nutrients, and are a very important economic source for the Brazilian Northeastern region. Unfortunately, an enormous quantity of this good raw material is wasted every year due to the short postharvest life associated with the small capacity for industrial use and the lack of economically viable techniques for raw material conservation (PAIVA et al., 2000).

The cashew apple is used mostly for the production of juice. Its residue is composed of the skin and the husk and is frequently used for animal feed or even wasted. The residue has a dark yellow color, a fibrous aspect, and a typical adstringent aroma due to the presence of tannins which could be a limiting factor for the acceptability of the cashew apple and the juice, especially in foreign countries (COSTA; LIMA; LIMA, 2003). More recently, many studies have been conducted to develop new cashew products and to make a better use of this source of dietary fibers.

Therefore, the main purpose of this work was to prepare hamburgers with partial substitution of the meat with cashew apple residue powder. Sensory analyses were performed, and

Received 15/3/2010

Accepted 3/11/2010 (004726)

${ }^{1}$ Departamento de Tecnologia de Alimentos, Universidade Federal do Ceará - UFC, Av. Mister Hull, CP 12168, CEP 60356-000, Fortaleza, CE, Brazil, e-mail: mafonso@ufc.br

2 Universidade Federal de Viçosa - UFV, Campus Universitário, Viçosa, MG, Brazil

* Corresponding author 
the determination of some quality characteristics of this product was also evaluated.

\section{Material and methods}

\subsection{Preparation of cashew apple residue powder}

The samples of the cashew apple residues were obtained after depulping and grinding using an industrial blender

The residues, $300 \mathrm{~g}$ of $1.0 \mathrm{~cm}$ thick samples, were submitted to processes such as washing, sanitization, and drying in an air circulation oven (aluminum trays) at $60{ }^{\circ} \mathrm{C}$ for 8 hours. The dried samples were ground using a domestic blender and sieved through a $0.6 \mathrm{~mm}$ mesh sieve.

\subsection{Preparation of hamburgers}

In order to prepare the hamburgers, ground beef muscle meat, powder from cashew apple residue, and a commercial mix composed of refined salt, monosodium glutamate, hydrolyzed vegetable protein, dehydrated onion, spices, antioxidant INS 316 , and flavoring natural aroma were used.

Four types of formulations were prepared in which the meat percentage varied from $81.42-95.69 \%$, and $0.0 \%$ (control) to $14,27 \%$ of cashew apple residue powder. The amount of ingredients was the same in the four formulations, as shown in Table 1.

The raw materials and ingredients were mixed for 10 minutes at an approximate temperature of- 3.0 to $-1.0{ }^{\circ} \mathrm{C}$. The hamburgers weighing at least $52 \mathrm{~g}$ were hand shaped in dischargeable petri dishes, packed in plastic bags, and stored in a freezer at $-18^{\circ} \mathrm{C}$.

\subsection{Determination of the centesimal composition of hamburger type products}

Analysis of moisture, $\mathrm{pH}$, and ashes were performed according to the standard analytical rules of the Instituto... (2005); lipids and proteins according to the Association... (1999); and total carbohydrates including dietary fiber and caloric value (Equation 1) according to Universidade... (2006).

$C V=(4 . P)+(4 .(C-D F)+(9 . L)$

Where, $\mathrm{CV}=$ caloric value $(\mathrm{kcal}) ; \mathrm{P}=$ total proteins $(\mathrm{g})$; $\mathrm{C}=$ carbohydrates $(\mathrm{g}) ; \mathrm{DF}=$ dietary fibers $(\mathrm{g}) ; \mathrm{L}=$ lipids $(\mathrm{g})$.

The total dietary fiber (TDF), insoluble dietary fiber (IDF), and soluble dietary fiber (SDF) analyses of the cashew apple residue were performed using the enzymatic gravimetric

Table 1. Hamburger formulations expressed in percentage per $100 \mathrm{~g}$ of sample.

\begin{tabular}{lccc}
\hline Formulation & Meat (\%) & Residue powder (\%) & Ingredients (\%) \\
\hline F1 (control) & 95.69 & 0.0 & 4.31 \\
F2 (7.13\%) & 88.56 & 7.13 & 4.31 \\
F3 (10.70\%) & 84.99 & 10.70 & 4.31 \\
F4 (14.27\%) & 81.42 & 14.27 & 4.31 \\
\hline
\end{tabular}

method of Prosky (ASSOCIATION..., 1999). The dietary fiber content in the hamburgers was determined based on the quantity of residues used in each formulation.

In order to compare the resulting composition of the hamburgers, information provided on the centesimal composition of five commercial brands was used.

\subsection{Physical analysis}

The yield percentage was calculated through the use of Equation 2, described by Berry (1992), in which the samples were weighed before and after cooking.

$Y=\left(\frac{m_{1}}{m_{2}}\right) \times 100$

Where, $Y=$ yield percentage $(\%) ; m_{1}=$ cooked sample mass $(\mathrm{g})$; $m_{2}=$ crude sample mass $(\mathrm{g})$.

The shortening percentage after cooking was obtained by measuring the hamburgers diameter using a digital pachymeter before and after cooking (BERRY, 1992) according to Equation 3.

$S=\left(\frac{d_{2}-d_{1}}{d_{2}}\right) \times 100$

Where, $S=$ shortening percentage $(\%) ; d_{1}=$ cooked sample mass (g); $d_{2}=$ crude sample mass $(\mathrm{g})$.

The analysis of the shearing power is associated to the product texture. This analysis was performed using the Warner-Bratzler shear device, operating at a speed of $3.3 \mathrm{~mm} / \mathrm{s}$, according to the method described by Ramos and Gomide (2007).

\subsection{Sensorial analysis of hamburger type products}

The sensory analysis was performed by 60 high school students. A nine-point hedonic scale was used combined with oral and facial expressions and numbers. The sensory characteristics evaluated were aroma, flavor, overall impression. Purchase intention was evaluated using a 5 point- hedonic scale.

During the sensory tests, the hamburgers were grilled in an electric grill for twelve minutes and were turned over every two minutes (SEABRA et al., 2002).

\subsection{Statistical analysis}

The results achieved were statistically treated by the ANOVA and Tukey test, at the level of $5 \%$ of significance (STATSOFT, 2005).

\section{Results and discussion}

\subsection{Centesimal composition, $\mathrm{pH}$ and caloric value of hamburger type products}

The results are shown in Table 2. It can be seen that moisture decreases with the addition of cashew apple residue powder $(\mathrm{p}<0.05)$. These results are similar to those found by Marques 
(2007) for beef hamburgers mixed with different amounts of oat fibers. The addition of residue caused a gradual reduction in the $\mathrm{pH}(\mathrm{p}<0.05)$. Lima (2008) formulated a pure vegetal hamburger based on cashew apple residue and found a little lower $\mathrm{pH}$, with a value of 4.75 . In the present study, it was found variation in the ash content $(\mathrm{p}>0.05)$, and the results were higher than those found by Seabra (2002) with 1.06 and $1.10 \%$ in hamburgers formulated with ovine (sheep) meat added to manioc flour and oatmeal. Meatballs added to rye bran presented a higher levels of ash ( $p>0.05)$ (YILMAZ, 2003).

Lipid percentage was reduced up to $35 \%(\mathrm{p}<0.05)$ with the addition of cashew apple residue, but the formulations F2, F3, and $\mathrm{F} 4$ can be considered as low fat products, when compared to F1 (control), due to the reduction of more than $25 \%$ of lipids (BRASIL, 1998).

Table 3 shows the centesimal composition of some hamburgers found on the label of five commercial products. The hamburgers of those commercial brands presented 13.7 to $17.5 \%$ of lipids according to their labels (Table 2). These values were higher than the others including the F1 values (control). This is due to the utilization of low fat hamburger in this study. Adding different portions of oatmeal to hamburgers, Marques (2007) found variations in the results; the highest values were found in the samples added to oatmeal due to the relatively high content of lipids in this flour, which does not happen to the cashew powder. Lima (2008) found $7.9 \%$ of lipids in a pure cashew hamburger. Garcia et al. (2002) added 1.5 and 3\% of dietary food fibers (peach, apple, and orange) to sausage and obtained a reduction of $35 \%$ in fat.

Desmond and Troy (1998) added tapioca starch, oat fibers, and whey protein as substitutes for fat in hamburgers, and the average of lipids content was $9.4 \%$, which is high when compared to that found in the present study.

Cashew apple presents low protein content; therefore, formulation F1 (control) presented difference ( $\mathrm{p}<0.05)$ compared ti the other formulations (F2,F3, and F4). The values are higher when compared to those of a study for a hamburger added to manioc flour (17.98\%) and a hamburger with oatmeal (18.09\%) (SEABRA et al., 2002). In another study, an average of $186 \mathrm{~g} . \mathrm{kg}^{-1}$ of proteins (DESMOND; TROY, 1998) was found, which is also higher in comparison to vegetal hamburgers prepared with cashew apple residue and spices (5.75\%) (LIMA, 2008). According to another research conducted with beef hamburgers of commercial brands, this work also presented better results.

The value of total carbohydrates increased with the amount of the cashew apple residue $(\mathrm{p}<0.05)$. The results were lower than those found by (LIMA, 2008), 33.99\%, for vegetal hamburger based on cashew. Marques (2007) obtained values varying from 2.82 to $15.02 \%$ for hamburgers added to oatmeal and control samples, which indicates that these values increase proportionally values with the addition of oatmeal to the hamburgures. Turhan (2005) used hazelnut pellicle in low fat hamburgers and also verified a gradual increase with the addition of the hazelnut pellicle.

The Brazilian Technical Regulations of Identity and Quality of meat (BRASIL, 2000) establishes that such products must have a minimal content of $15 \%$ proteins and maximum of $3 \%$ of total carbohydrates. According to Table 2, all of the developed products meet the protein standards; however, as for the carbohydrates, only F1 is meets the regulations, and therefore F2, F3, and F4 cannot be named as hamburgers, but "hamburger type" products.

The total dietary fiber content was between 0 and $7.66 \%$, with higher content of insoluble dietary fiber between 0 and $6.95 \%$. Therefore, formulations F2 and F3 can be considered fiber source products since they present more than 3 g. $100 \mathrm{~g}^{-1}$, and $\mathrm{F} 4$ can be considered a high fiber content product due to its higher dietary fiber content 6 g.100 g ${ }^{-1}$ (BRASIL, 1998).

Hamburgers with the addition of $6.88-25 \%$ of oatmeal presented $3.99-7.58 \%$ of total dietary fiber content, which indicates that to reach fiber contents close those found with

Table 3. Caloric value, carbohydrates, proteins, lipids and fibers in a $100 \mathrm{~g}$ portion of five commercial brands of hamburger.

\begin{tabular}{lrrrrr}
\hline \multicolumn{1}{c}{ Composition } & Brand 1 & Brand 2 & Brand 3 & Brand 4 & Brand 5 \\
\hline Caloric value (kcal) & 199.0 & 225.0 & 225.0 & 234.0 & 183.0 \\
Carbohydrates (\%) & 2.5 & 2.5 & 3.0 & 2.5 & 3.5 \\
Proteins (\%) & 16.3 & 16.3 & 15.0 & 17.5 & 10.5 \\
Lipids (\%) & 13.7 & 17.5 & 17.5 & 17.5 & 13.7 \\
Fibers (\%) & 0.0 & 0.0 & 0.0 & 0.0 & 0.0 \\
\hline
\end{tabular}

Table 2. Centesimal composition of hamburger type products.

\begin{tabular}{lcccc}
\hline Composition & F1 & F2 & F3 & F4 \\
\hline Moisture (\%) & $71.10^{\mathrm{a}} \pm 0.25$ & $69.29^{\mathrm{b}} \pm 0.03$ & $66.12^{\mathrm{c}} \pm 1.00$ & $63.38^{\mathrm{d}} \pm 0.09$ \\
Ph & $6.07^{\mathrm{a}} \pm 0.01$ & $5.71^{\mathrm{b}} \pm 0.00$ & $5.56^{\mathrm{c}} \pm 0.01$ & $5.33^{\mathrm{d}} \pm 0.00$ \\
Ash (\%) & $4.00^{\mathrm{a}} \pm 0.01$ & $3.95^{\mathrm{a}} \pm 0.04$ & $3.86^{\mathrm{a}} \pm 0.03$ & $3.71^{\mathrm{a}} \pm 0.4$ \\
Lipids (\%) & $2.05^{\mathrm{a}} \pm 0.03$ & $1.64^{\mathrm{b}} \pm 0.12$ & $1.41^{\mathrm{bc} \pm 0.14}$ & $1.34^{\mathrm{c}} \pm 0.09$ \\
Proteins (\%) & $22.45^{\mathrm{a}} \pm 0.23$ & $20.84^{\mathrm{b}} \pm 0.90$ & $20.53^{\mathrm{b}} \pm 0.45$ & $20.60^{\mathrm{b}} \pm 0.38$ \\
Carboh.tot. (\%) & $0.39^{\mathrm{a}} \pm 0.24$ & $4.28^{\mathrm{b}} \pm 0.77$ & $8.08^{\mathrm{c}} \pm 0.83$ & $10.96^{\mathrm{d}} \pm 0.30$ \\
Calories (kcal) & $109.80^{\mathrm{a}} \pm 0.85$ & $99.92^{\mathrm{b}} \pm 0.58$ & $104.14^{\mathrm{ab}} \pm 4.47$ & $107.67^{\mathrm{a}} \pm 1.72$ \\
TDF (\%) & 0.0 & 3.83 & 5.75 & 7.66 \\
IDF (\%) & 0.0 & 3.47 & 5.21 & 6.95 \\
SDF (\%) & 0.0 & 0.36 & 0.54 & 0.72 \\
\hline
\end{tabular}

(F1) control; (F2) $7.13 \%$ of powder residue; (F3) $10.70 \%$ of powder residue; (F4) $14.27 \%$ of powder residue. TDF (total dietary fiber); IDF (insoluble dietary fiber); SDF (soluble dietary fiber). Means followed by the same letter in the same line are not significant different $(\mathrm{p}>0.05)$. 
cashew apple residues, it is necessary to add a larger quantity of oatmeal to the product (MARQUES, 2007).

Regarding caloric value, no statistical difference $(\mathrm{p}>0.05)$ was found among the formulations F1, F3, and F4, but in the samples with the addition of cashew apple residue (F2, F3, and F4) the caloric value is mainly a result of the increase of the total carbohydrates percentage, different from F1 and from the majority of meat products in which the high caloric value is related mainly to the fat content. The results obtained in the present study were lower than those of the commercial brands analyzed, which according to their labels ranged from 183.0 to $234.0 \mathrm{kcal}$. Mansour and Khalil (1997) obtained a reduction of $6-42 \%$ in the caloric value of hamburgers with the addition of wheat fiber.

\subsection{Physical analysis of hamburger type products}

The results for yield analysis and shearing force are shown in Table 4. It can be noticed that the best yield and the least shortening percentage were obtained with the increase of cashew apple residue powder in the formulations. This is due to the lower water and residue concentration, which were partially lost during the cooking process.

With regard to the yields, there was no statistical difference ( $p>0.05$ ) between the formulations F2 and F3. On the other hand, between F1 and F4 samples, with higher and lower concentrations of cashew apple residues, respectively, there was a significant difference $(\mathrm{p}<0.05)$. Sheep meat hamburger added with manioc flour or oatmeal produced lower yield (SEABRA, 2002). Desmond and Troy (1998) obtained an improvement in the yield of hamburgers adding manioc starch and oat fiber.

The percentage of shortening after cooking showed best results for the formulations F2, F3, and F4, with a difference $(\mathrm{p}<0.05)$ only between these formulations and F1. Similar results were obtained by Seabra (2002). Mansour and Khalil (1997) added up to $15 \%$ of wheat flour to hamburgers and observed a significant improvement in yield and shortening percentage when compared to that of the control sample.

There was statistical difference $(\mathrm{p}<0.05)$ among all formulations in the analysis of shearing force. The samples F1 and F4 shown the least less shear force. This is probably due to the higher water and fat content in F1 and to the large amount of cashew apple powder residue in $\mathrm{F} 4$, which hindered the agglutination of the hamburger contents.

Another factor that might have contributed to the increase in the product shearing force is the strong presence of insoluble dietary fibers related to soluble dietary fibers since the last one shows a higher water absorbing and gel formation capacity, which directly influences the improvement of the product texture. Seabra (2002) obtained lower shearing force for hamburgers with the addition of manioc flour and oatmeal. However, Desmond and Troy (1998) verified an increase in the Warner-Bratzler shear force by for hamburgers mixed with manioc starch.

\subsection{Sensorial analysis of hamburger type products}

Table 5 presents the results of the sensory analysis. Formulation F1 presented the best results for aroma, overall impression and purchase intention. However, it was observed that even with a significant difference the scores given by the tasters were very similar, especially between F1 and F2.

Concerning the flavor, there was no difference between F1, F2, and F3, which presented sensory scores varying from "disliked lightly and neither liked nor dislike". The decreasing scores with the increasing addition of the cashew apple residue could be a consequence of the presence of tannins, which can influence negatively the acceptation of the product.

It was observed that that even with the formulation without the cashew apple residue (F1) the results had a maximum average score of 6.4 , which is the equivalent to the sensory score between "liked lightly" and "neither liked nor dislike". This means that the decreasing scores for the other formulations can be related not only to the addition of the residue powder, but also to the techniques for the elaboration of the hamburgers and formulations.

A study with cereals and fruit dietary fibers in sausages, obtained an acceptable sensorial profile. The best results were obtained with the addition of up to $1.5 \%$ of fruit fibers, specially peach, due to its flavor, and orange, which showed the best texture due to its high pectin content, a soluble dietary fiber responsible for water absorption and gel formation (GARCÍA, 2002).

Lima (2008) prepared a vegetable hamburger using cashew and flavoring. The sensorial results average was "liked it" (LIMA, 2008). Galvão (2006) elaborated a vegetal hamburger with cashew apple residues and spices and compared it to a beef hamburger from a commercial brand; the scores given to the

Table 5. Average scores of the sensorial analysis.

\begin{tabular}{lcccc}
\hline \multicolumn{1}{c}{ Parameters } & F1 & F2 & F3 & F4 \\
\hline Aroma & $5.8^{\mathrm{a}}$ & $4.8^{\mathrm{b}}$ & $4.4^{\mathrm{bc}}$ & $3.5^{\mathrm{c}}$ \\
Flavor & $6.4^{\mathrm{a}}$ & $5.8^{\mathrm{ab}}$ & $4.5^{\mathrm{ab}}$ & $3.7^{\mathrm{b}}$ \\
Global impression & $6.3^{\mathrm{a}}$ & $5.1^{\mathrm{b}}$ & $4.7^{\mathrm{bc}}$ & $4.1^{\mathrm{c}}$ \\
Purchase intention (\%) & 32.7 & 23.3 & 19.8 & 16.5 \\
\hline \multicolumn{7}{l}{ Means followed by the same letter in the same line are not significant different $(\mathrm{p}>0.05)}$.
\end{tabular}

Table 4. Shrinkage, cooking yield, and shearing force analysis of hamburger type products.

\begin{tabular}{|c|c|c|c|c|}
\hline Analysis & F1 & $\mathrm{F} 2$ & F3 & $\mathrm{F} 4$ \\
\hline Yield (\%) & $70.23^{a} \pm 6.61$ & $75.73^{\mathrm{ab}} \pm 6.09$ & $79.38^{\mathrm{ab}} \pm 4.48$ & $88.52^{\mathrm{b}} \pm 3.04$ \\
\hline Shortening (\%) & $23.65^{\mathrm{a}} \pm 0.54$ & $14.42^{\mathrm{b}} \pm 3.73$ & $12.97^{\mathrm{b}} \pm 2.31$ & $12.45^{\mathrm{b}} \pm 2.99$ \\
\hline Shearing force (kgf) & $3.88^{\mathrm{a}} \pm 0.20$ & $4.43^{\mathrm{b}} \pm 0.10$ & $4.86^{c} \pm 0.16$ & $3.36^{\mathrm{d}} \pm 0.80$ \\
\hline
\end{tabular}

(F1) control; (F2) $7.13 \%$ of powder residue; (F3) $10.70 \%$ of powder residue; (F4) $14.27 \%$ of powder residue. Means followed by the same letter in the same line are not significant different $(\mathrm{p}>0.05)$. 
sensory attributes aroma, flavor, and global impression were similar for both products.

Turhan (2005) reported scores from 4.12 to 6.76 for global acceptation for hamburgers added with hazel-nut film. Yilmaz (2003) substituted the fat with rye meal in meat balls. The samples with 5 and $10 \%$ of meal presented high acceptability. Ginés et al. (2006) added fibers from citric products in sausages with different concentrations; all samples obtained satisfactory quality, except for those with $2 \%$ of fiber.

\section{Conclusion}

The production of hamburgers with partial substitution of beef with cashew apple residue improved the product, which presented high nutritional quality and was rich in or had high dietary fiber content and low in fat when compared to conventional ones, and was higher in proteins when compared to vegetable hamburgers. They produced a good yield and a lower rate of shortening when compared to the control sample.

The addition of up to $10.7 \%$ of cashew apple residue did not change significantly the sensorial impacts in terms of taste when compared to the control sample. Therefore, the product prepared with partial substitution of meat with this residue can be considered a very feasible product to be commercialized in food Market.

\section{Acknowledgements}

The authors are grateful for the financial support provided by CAPES - Brazilian research supporting foundation (Coordenação de Aperfeiçoamento de Pessoal de Nível Superior-CAPES of the Ministry of Education (MEC).

\section{References}

ASSOCIATION OF OFFICIAL ANALYTICAL CHEMISTS - AOAC. Official Methods of Analysis of the Association of Official Analytical Chemists. 15. ed. Washington: AOAC, 1999. 2 v.

BERRY, B. W. Low fat level effects on sensory, shear, cooking and chemical properties of ground beef patties. Journal of food science, v. 57, n. 3, p. 537, 1992. http://dx.doi.org/10.1111/j.1365-2621.1992.tb08037.x

BRASIL. Ministério da Agricultura e Abastecimento. Instrução Normativa $\mathrm{n}^{\circ} 20$, de 31 de julho de 2000. Regulamento Técnico de Identidade e Qualidade de Hambúrguer. Diário Oficial da República Federativa do Brasil, Brasília, DF, 31 jul. 2000. Anexo IV.

BRASIL. Portaria SVS no 27, de 13 janeiro de 1998. Regulamento Técnico referente a Informação Nutricional Complementar. Diário Oficial da República Federativa do Brasil, Brasília, DF, 16 jan. 1998. Seção 1.

COSTA, T. S. A.; LIMA A.; LIMA, M. V. Determinação de tanino em pedúnculo de caju: método da vanilina versus método do butanol ácido. Química Nova, v. 26, n. 5, p. 763-765, 2003.
DESMOND, E. M., TROY, D. J. The effects of tapioca starch, oat fibre and whey protein on the physical and sensory properties of low-fat beef burgers. Lebensmittel-Wissenschaft und-Technologie, v. 31, p. 653-657, 1998.

GALVÃO, A. M. P. Aproveitamento da fibra de caju (Anacardium occidentale 1.) na formulação de um produto tipo hambúrguer. 2006. $64 \mathrm{f}$. Dissertação (Mestrado em Tecnologia de Alimentos)-Centro de Ciências Agrárias, Universidade Federal do Ceará, Fortaleza, 2006.

GARCÍA, M. L. et al. Utilization of cereal and fruit fibres in low fat dry fermented sausages. Meat science, v. 60, p. 227-236, 2002. http:// dx.doi.org/10.1016/S0309-1740(01)00125-5

GINÉS, J. M. F. et al. Effect of storage conditions on quality characteristics of bologna sausages made with citrus fiber. Journal of food science, v. 68, n. 2, p. 710-714, 2006.

INSTITUTO ADOLFO LUTZ - IAL. Normas analíticas do Instituto Adolfo Lutz: métodos físicos e químicos para a análise de alimentos. 3. ed. São Paulo: IAL, 2005.

JONNALAGADDA, S. S.; JONES, J. M. Position of the American Dietetic Association: fat replacers. Journal of the American Dietetic Association, v. 105, p. 266-275, 2005. PMid:15668687. http://dx.doi.org/10.1016/j.jada.2004.12.011 LIMA, J. R. Caracterização físico-química e sensorial de hambúrguer vegetal elaborado à base de caju. Ciências agrotécnicas, v. 32, n. 1, p. 191-195, 2008.

MANSOUR, E. H.; KHALIL, A. H. Charachteristics of low-fat beefburger as influenced by various types of wheat fibers. Food research International, v. 30, p. 199-205, 1997. http://dx.doi. org/10.1016/S0963-9969(97)00043-4

MARQUES, J. M. Elaboração de um produto de carne bovina "tipo hambúrguer" adicionado de farinha de aveia. 2007. $55 \mathrm{f}$. Dissertação (Mestrado em Tecnologia de Alimentos)-Universidade Federal do Paraná Curitiba, 2007.

PAIVA, F. F. A.; GARRUTI, D. S; NETO, R. M. S. Aproveitamento industrial do caju. Fortaleza: CNPAT/SEBRAE/EMBRAPA, 2000.

RAMOS, E. M.; GOMIDE, L. A. M. Avaliação da qualidade de carnes: fundamentos e metodologias. Viçosa: UFV, 2007.

SEABRA, L. M. A. J. et al. Fécula de mandioca e farinha de aveia como substitutos de gordura na formulação de hambúrguer de carne ovina. Ciência e tecnologia de alimentos, v. 22, n. 3, p. 244248, 2002.

STATSOFT. Statsoft 7.0 for windows. Tucksa: Statsoft Inc., 2005.

TURHAN, S.; SAGIR, I.; USTUN, N. S. Utilization of hazelnut pellicle in low-fat beef burgers. Meat Science, v. 71, p. 312-316, 2005. http:// dx.doi.org/10.1016/j.meatsci.2005.03.027

UNIVERSIDADE DE CAMPINAS - UNICAMP. Tabela brasileira de composição de alimentos - TACO. Versão 2. 2. ed. Campinas: UNICAMP/NEPA, 2006.

YILMAZ, I. Effectsof rye bran addition on fatty acid composition and quality characteristics of low-fat meatballs. Meat Science, v. 67, p. 245-249, 2003. http://dx.doi.org/10.1016/j. meatsci.2003.10.012 